Marek REWIZORSKI

Politechnika Koszalińska

\title{
Podmiotowość prawnomiędzynarodowa Wspólnot Europejskich oraz Unii Europejskiej
}

\section{Wprowadzenie}

$\mathrm{D}$ ebata nad przyszłością Unii Europejskiej, której impulsem przed laty stał się Traktat z Nicei, jest okazją do zastanowienia się nad fundamentalnymi pytaniami dotyczącymi statusu prawnego ugrupowania integracyjnego powstałego w 1992 r. na bazie trzech Wspólnot Europejskich zawiązanych w latach 50-tych. Watpliwości spotęgowane są faktem braku pełnej akceptacji, wśród narodów państw UE, co do reformy jej funkcjonowania, czego przykładem są zakończone niepowodzeniami referenda w sprawie przyjęcia Traktatu konstytucyjnego (2005 r.) oraz Traktatu z Lizbony (2007 r.). Taki stan rzeczy nie napawa optymizmem, zwłaszcza w najbliższym czasie, kiedy trzeba będzie uporać się z takimi problemami jak ustalenie w praktyce przejrzystych zasad podziału kompetencji pomiędzy Unią a państwami członkowskimi oraz zwiększenie zakresu jej legitymizacji demokratycznej poprzez szersze niż do tej pory włączenie parlamentów narodowych w procesy podejmowania decyzji na poziomie europejskim. Rozwiązanie tych kwestii wydaje się być problematyczne bez poszerzenia refleksji nad zagadnieniami natury zasadniczej, wśród których szczególne znaczenie ma kwestia umocowania działalności Unii Europejskiej na arenie międzynarodowej i jej charakteru prawnego.

\section{Uwagi ogólne na temat podmiotowości prawnej}

W dużym uproszczeniu podmiotem $\mathrm{w}$ danym systemie prawnym jest ten, kto z faktu uczestnictwa w nim wywodzi dla siebie określone prawa i jednocześnie musi wypełniać nałożone na niego zobowiązania. Podmiotowość jest cechą przypisywaną zarówno podmiotom krajowym, jak również międzynarodowym. Przez długi czas przymiot bycia podmiotem prawa międzynarodowego przypisywano jedynie państwom. Według klasycznego, w nauce polskiego prawa międzynarodowego, ujęcia prezento- 
wanego w latach 60. ubiegłego wieku przez A. Klafkowskiego: „pojęcie podmiotu prawa obejmuje dwa składniki: zdolność prawną, czyli zdolność do tego, żeby być podmiotem praw i obowiązków oraz zdolność do działania, czyli zdolność do wykonywania samodzielnie określonych czynności ze skutkiem prawnym"1. Autor ten wychodząc od powyższej, generalnej definicji podmiotu prawa zakłada, że podmiotowość prawnomiędzynarodowa jest zdolnością nabywania praw i zaciagania zobowiązań międzynarodowych. Jego zdaniem odpowiedź na pytanie kto jest podmiotem prawa międzynarodowego przesądza w znacznej mierze praktyka państw, bowiem pojęcie podmiotu prawa międzynarodowego jest nierozdzielnie związane $\mathrm{z}$ suwerennością jako integralnym składnikiem państwa $^{2}$. Zgodnie z powyższym tokiem rozumowania, nie istnieje inny podmiot prawa międzynarodowego aniżeli państwo. Wynika to z faktu, że prawo międzynarodowe jest tworzone przez państwa, a zatem jedynie one mogą powoływać nowe instytucje - w tym organizacje międzynarodowe. Powyższy pogląd znalazł poparcie nie tylko wśród prawników, lecz także u niektórych przedstawicieli nauki o stosunkach międzynarodowych. Utrzymują oni, iż harmonijny rozwój stosunków międzynarodowych stanowi wypadkową działań podejmowanych przez niezależne i suwerenne państwa. Przedstawicielami tego sposobu myślenia są m.in. K. Waltz (uznawany za twórcę teorii strukturalnego realizmu w stosunkach międzynarodowych) oraz zaliczani do nurtu neorealistycznego R. Gilpin, J. Nye oraz F. Kratochwil. Argument o nadrzędności państw w systemie międzynarodowym uzasadniają oni poprzez odwołanie do zasad XVII-wiecznego porządku międzynarodowego usankcjonowanego traktatem westfalskim ${ }^{3}$. Obrazowo przedstawił tenże system $\mathrm{K}$. Waltz, porównując ukształtowane po traktacie westfalskim stosunki międzynarodowe do teatru, w którym państwa pisały scenariusze i grały główne role dramatu, a aktorzy niepaństwowi odgrywali jedynie role epizodyczne w ramach głównych wątków akcji ${ }^{4}$.

Z ujęciem neorealistycznym kontrastuje idea neoliberalna, której rdzeniem jest przekonanie o istnieniu wielocentrycznego świata scalonego przez ideę globalizacji, gdzie państwa wciąż zachowują nadrzędną pozy-

1 A. Klafkowski, Prawo międzynarodowe publiczne, Warszawa 1966, s. 59.

2 Ibidem, s. 60.

3 Traktat westfalski jest pojęciem zbiorczym, poprzez które rozumie się dwa traktaty: w Münster oraz w Osnabrück.

4 Por. P. Hirst, P. G. Thompson, Globalisation and the Nation State, w: The Handbook of Globalisation. ed. J. Michie, Chaltenham 2003, s. 290. 
cję w systemie międzynarodowym. Jednakże coraz częściej skłaniają się ku współdziałaniu z podmiotami niepaństwowymi, bez których pomocy nie mogą w pełni realizować swoich zadań. Do najważniejszych zaliczają się organizacje międzynarodowe, które według neoliberałów zajmują odrębną, szczególną pozycję w stosunkach międzynarodowych, występując w nich, zależnie od okoliczności, w roli: autonomicznego podmiotu prawa międzynarodowego lub/i podmiotu gospodarki światowej. Stanowisko to, przeważające wśród przedstawicieli doktryny stosunków międzynarodowych, po drugiej wojnie światowej zyskało także silną podbudowę prawną. Podstawowe znaczenie miała $\mathrm{w}$ tym zakresie opinia doradcza Międzynarodowego Trybunału Sprawiedliwości z 1949 r., w której stwierdzono, że organizacje międzynarodowe mają zasadniczo podmiotowość prawną, jeżeli na podstawie ich statutu można dojść do wniosku, że dla osiągnięcia swoich celów mogą zawierać umowy z państwami trzecimi (ius contrahendi), mają prawo korzystania z przywilejów i immunitetów, prawo czynnej i biernej legacji (ius legationis) oraz posiadają zdolność do czynności prawnych (mogą podejmować czynności prawnomiędzynarodowe $)^{5}$. Pomimo, że obecnie pogląd o posiadaniu przez organizacje międzynarodowe podmiotowości prawnomiędzynarodowej przeważa w nauce prawa międzynarodowego, to wciąż roztrząsany jest szereg związanych z tym kwestii prawnych.

Przykładem ich jest tocząca się współcześnie dyskusja o zakresie podmiotowości organizacji międzynarodowych. Zadaniem J. Barcza punktem wyjścia w dyskusji jest założenie, że organizacja ma podmiotowość prawnomiędzynarodową $\mathrm{w}$ zakresie przyznanym w umowie międzynarodowej (statucie) przez państwa założycielskie (członkowskie). W takim ujęciu jest to podmiotowość pochodna (wtórna) ${ }^{6}$. Zwolennikami tego poglądu są neorealiści. Według K. Waltza, R. Gilpina i J. Mersheimera, organizacje międzynarodowe poprzez pełnione funkcje realizują jedynie pewne cele zbiorowe wyznaczane i określane przez państwa założycielskie. Z kolei zdaniem ich protagonistów w dyskusji (funkcjonalistów), opierających się na doktrynie „domniemania kompetencji” (implied powers) kompetencje organizacji są wynikiem dynamicznego i niezależnego ich rozwoju od państw ${ }^{7}$.

5 ICJ Rep. 1949, s. 178 i n.

6 Prawo Unii Europejskiej, pod red. J. Barcza, Warszawa 2006, s. 27.

7 Funkcjonaliści twierdzą, iż podmiotowość pierwotna organizacji międzynarodowych wynika $\mathrm{z}$ doktryny kompetencji domniemanych ( $\mathrm{z}$ ang. implied powers), wy- 
Innym zagadnieniem pojawiającym się przy ocenie zakresu podmiotowości organizacji międzynarodowej jest to, czy można ją rozpatrywać na gruncie prawa krajowego. Odpowiedzi na to pytanie dostarcza praktyka państw, które godząc się na ustanowienie organizacji międzynarodowej za pomocą umowy jednocześnie przyznają jej w tym akcie prawnym podmiotowość $\mathrm{w}$ prawie wewnętrznym.

\section{Podmiotowość prawnomiędzynarodowa Wspólnot Europejskich}

Zgodnie z rozpowszechnionym poglądem Wspólnoty Europejskie, funkcjonujące przed wejściem w życie Traktatu z Lizbony, były uważane za organizacje międzynarodowe, powstałe w wyniku podpisania przez sygnatariuszy (państwa) umowy międzynarodowej ${ }^{8}$. Oznacza to, że ich podmiotowość miała charakter wtórny, ponieważ jej istnienie wypływało z suwerennej decyzji państw.

Warto wskazać, że spośród trzech Wspólnot Europejskich najpełniej cecha bycia podmiotem prawa międzynarodowego została uzewnętrzniona w podpisanym 18 kwietnia 1951 r. w Paryżu - Traktacie ustanawiającym Europejską Wspólnotę Węgla i Stali ( $\mathrm{z}$ fr. Communauté européenne du Carbon et de l'Acier-CECA). Jak wynika z art. 6 tegoż aktu: „Wspólnota posiada osobowość prawną. W stosunkach międzynarodowych Wspólnota posiada zdolność do czynności prawnych niezbędną dla wykonywania jej funkcji i osiagnnięcia jej celów”. W pozostałych traktatach rozważana

wiedzionej z opinii doradczej MTS dotyczącej odszkodowania za straty poniesione w służbie Organizacji Narodów Zjednoczonych (1949). Na gruncie prawa wspólnotowego uszczegółowienie tej doktryny nastąiło poprzez orzecznictwo ETS, głównie w zakresie Wspólnej Polityki Rolnej oraz stosunków zewnętrznych Wspólnot. Istnieje ponadto pogląd jakoby niezależność i pierwotny charakter praw przysługujących organizacjom międzynarodowym mogła być domniemywana ex natura, a zatem posiadałyby one wszystkie prawa, które dane są pozostałym, samodzielnym podmiotom prawa międzynarodowego, a jedynym ich ograniczeniem miałyby być postanowienia statutu organizacji.

${ }^{8} \mathrm{~W}$ praktyce prawnej umowy międzynarodowe będące podstawą działania organizacji międzynarodowych są najczęściej nazywane statutami, traktatami konstytucyjnymi bądź układami podstawowymi. W razie wątpliwości co do charakteru prawnego aktu wywierającego skutki w stosunkach międzynarodowych należy stosować regułę interpretacyjna, zgodnie z którą nie nazwa, lecz treść aktu prawnego decyduje o jego kwalifikacji prawnej (z łac. rubrica legis non est lex - tytuł przepisu prawa nie jest prawem). 
kwestia potraktowana została bardziej ogólnikowo. Zarówno w Traktacie o utworzeniu Wspólnoty Europejskiej (art. 281 TWE), jak również Traktacie o Europejskiej Agencji Energii Atomowej (art. 184 TEWEA) znaleźć można lakoniczny zapis o tym, że: „Wspólnota posiada osobowość prawną”. Analiza powołanych treści przepisów, ze względu na ich ogólnikowość, może nastręczać pewnych trudności interpretacyjnych. Dotyczą one m.in.:

1) przyjęcia metody, z pomocą której możliwe jest wyjaśnienie zagadnienia podmiotowości prawnomiędzynarodowej Wspólnot, a także

2) określenia kierunku działań podejmowanych przez Wspólnoty (podmiotowość zewnętrzna czy wewnętrzna).

Na wstępie bardziej szczegółowych rozważań warto zaznaczyć, że analizując zagadnienie podmiotowości Wspólnot Europejskich należy mieć na względzie przede wszystkim WE i EWEA. Powodem tego jest fakt wygaśnięcia 23 lipca 2002 r. obowiązywania Traktatu o EWWiS, który w przeciwieństwie do Traktatów Rzymskich nie został zawarty na czas nieokreślony, ale na okres 50 lat ${ }^{9}$. Wykładnia językowa zapisów trzech traktatów dotyczących podmiotowości prawnomiędzynarodowej Wspólnot świadczy o tym, że funkcjonalny jej charakter został expressis verbis wskazany tylko w Traktacie Paryskim konstytuującym Wspólnotę Węgla i Stali. Świadczy o tym bezpośrednie związanie zdolności do podejmowania przez nią działań przewidzianych przez prawo z jej funkcjami i celami. Ogólnie rzecz biorąc EWWiS miało stanowić ponadnarodowe ugrupowanie gospodarcze, kontrolujące produkcję węgla i stali w państwach członkowskich. Przysługująca mu podmiotowość prawna miała wymiar zewnętrzny, a sama organizacja ze względu na traktatowe regulacje dotyczące hutnictwa i górnictwa stała się instrumentem integracji sektorowej.

Porównanie art. 6 TEWWiS z art. 281 TWE i 184 TEWEA pozwala jednak na dostrzeżenie związku pomiędzy ideą integracji a podmiotowością Wspólnot. Widać tutaj pewną niekonsekwencję państw członkowskich, które z jednej strony wyraźnie wskazały na sektorowy charakter EWWiS poprzez nadanie tej ostatniej podmiotowości funkcjonalnej, a z drugiej zaś zaniechały sprecyzowania charakteru podmiotowego jedy-

9 Sprawa EWWiS została ostatecznie rozstrzygnięta podczas konferencji w Nicei (2001 r.), w czasie której przyjęto Protokół o skutkach finansowych wygaśnięcia Traktatu ustanawiającego EWWiS oraz o Funduszu Badań Węgla i Stali. Zgodnie z jego treścią wszystkie zobowiązania wskazanej wyżej Wspólnoty istniejące w dniu 23 lipca 2002 r. przeszły na Wspólnotę Europejską (d. Europejską Wspólnotę Gospodarczą - EWG) 24 lipca 2002 r. 
nej działającej obecnie Wspólnoty - EWEA, która również ma ograniczony zakres działania i cele ${ }^{10}$. W rezultacie, okres przedlizboński charakteryzował spór dotyczący stosunku całościowej integracji gospodarczej (TWE) do integracji sektorowej (TEWWiS, TEWEA), a także wątpliwości wynikające z pytania o to jak rozumieć tożsame pod względem semantycznym postanowienia TWE i TEWEA dotyczące podmiotowości.

Zgodnie $\mathrm{z}$ rozpowszechnionym $\mathrm{w}$ doktrynie prawa europejskiego poglądem Traktaty o Euratomie i EWWiS uzyskały charakter szczególny odmiennie od TWE, w stosunku do którego ze względu na ogólny charakter, a także całościowy zakres przewidzianej integracji użyto przymiotnika „ramowy”"11. Jednocześnie przyjmuje się, że stosunek pomiędzy TWE a pozostałymi Traktatami był taki, jak między leges generales a leges speciales. Oznacza to, że pierwszy z aktów miał zastosowanie jedynie wtedy kiedy postanowienia TEWEA nie były dostatecznie wyczerpujące, lub gdy brakowało w nim określonych regulacji ${ }^{12}$. Przyjęcie powyższego stanowiska prowadzi do wniosku, że zapis „Wspólnota posiada osobowość prawną", zamieszczony w art. 281 TWE i 184 TWEA różnił się pod względem zakresu zastosowania, trudno bowiem zakładać, aby Wspólnota „sektorowa” mogła wykonywać zadania powierzone WE tym bardziej, że zdolność do czynności prawnych tej ostatniej trzeba było interpretować $\mathrm{w}$ związku $\mathrm{z}$ celami zawartymi w art. 2 TWE.

Kolejna kwestia wymagająca interpretacji przy okazji rozważań nad podmiotowością Wspólnot była związana z koniecznością odpowiedzi na pytanie czy osobowość prawna z art. 281 TWE i 184 TEWEA odnosiła się do prawa wewnętrznego państw członkowskich, czy też sfery prawa międzynarodowego. W doktrynie prawa europejskiego wyrażono pogląd o podmiotowości „na zewnątrz”. Na rzecz podmiotowości prawnomiędzynarodowej Wspólnot (WE, EWEA) przemawiał fakt, że przepisy obu traktatów znajdujące się po postanowieniach wskazujących na posiadanie przez nie osobowości prawnej, dotyczyły in toto podmiotowości w prawie wewnętrznym państw członkowskich ${ }^{13}$.

10 Jako najważniejsze zadania EWEA określono: przyczynianie się do powstania i szybkiego rozwoju przemysłu jądrowego, podwyższenie poziomu życia w państwach członkowskich, rozwój wymiany z innymi krajami.

11 M. Schweitzer, W. Hummer, Europarecht. Das Recht der Europäischen Gemeinschaften (EKGS, EWG, EAEG) - mit Schwerpunkt EG, Berlin 1996, s. 32.

12 J. Tyranowski, Prawo europejskie, Poznań 2005, s. 51.

13 Dla przykładu w art. 282 TWE znajduje się zapis, zgodnie z którym: „W każdym z Państw Członkowskich Wspólnota posiada zdolność prawną i zdolność do 
Fundamentalną rolę w wyjaśnieniu zagadnienia podmiotowości prawnomiędzynarodowej Wspólnot przypadła Europejskiemu Trybunałowi Unii Europejskiej (dawniej ETS), który zgodnie z art. 19 nowego Traktatu o Unii Europejskiej (dawniej art. 220 TWE i 136 TEWEA) w zakresie swojej właściwości czuwa nad poszanowaniem prawa w wykładni i stosowaniu przepisów traktatowych ${ }^{14}$. W znanym orzeczeniu z 15.07.1964 r. w sprawie 6/64 Flamino Costa v. E.N.E.L, zawisłej przed TS na skutek pytania prejudycjalnego o zgodność włoskiej ustawy nr 1643 z 6 grudnia 1962 r. umożliwiającej nacjonalizację wytwarzania i dystrybucji energii elektrycznej z ówczesnymi art. 37, 53, 93 i 102 TEWG stwierdził on m.in., że: „,...] Poprzez utworzenie na czas nieograniczony Wspólnoty, posiadającej własne organy, wyposażonej w osobowość prawną, w zdolność prawną i zdolność do reprezentacji w sferze międzynarodowej, a w szczególności w prawa suwerenne wywodzące się z ograniczenia kompetencji państw członkowskich lub z przekazania przez państwa członkowskie swych uprawnień Wspólnocie, państwa członkowskie ograniczyły swoje prawa suwerenne i przez to utworzyły korpus prawa, które jest wiążące dla ich obywateli i dla nich samych"15.

Powyższe stanowisko zostało podtrzymane i rozwinięte przez Trybunał w kolejnych orzeczeniach. W sprawie 22/70 Komisja Wspólnot Europejskich v. Rada Wspólnot Europejskich (sprawa ERTA) Trybunał wskazał explicite, iż: ,[...] 13. Artykuł 210 TWE stanowi, że «Wspólnota ma osobowość prawną». 14. To postanowienie, umieszczone na początku Części Szóstej Traktatu, poświęconej «Postanowieniom ogólnym i końcowym» oznacza, że w relacjach zewnętrznych Wspólnota ma zdolność do ustanawiania stosunków umownych z krajami trzecimi w zakresie celów zdefiniowanych w Części I Traktatu, którą uzupełnia Część VI. 15. W celu ustalenia, czy w konkretnym przypadku Wspólnota ma prawo do przystąpienia do umów międzynarodowych, należy uwzględnić całą systematykę Traktatu, w stopniu nie mniejszym niż treść jego najważniejszych

czynności prawnych o najszerszym zakresie przyznanym przez ustawodawstwa krajowe osobom prawnym; może ona nabywać lub zbywać mienie ruchome i nieruchome oraz stawać przed sądem".

14 Wersja skonsolidowana Traktatu o Unii Europejskiej, Dziennik Urzędowy Unii Europejskiej, C 115, Tom 51, 9 maja 2008, s. 27.

${ }_{15}$ Sprawa 6/64, Flamino Costa v. ENEL, Zb. Orz. 1964, s. 585, w: Prawo Wspólnot Europejskich. Orzecznictwo, W. Czapliński, R. Ostrihansky, P. Saganek, A. Wyrozumska, Warszawa 2005, s. 36. 
postanowień. 16. Kompetencja taka [tzn. do zawierania umów międzynarodowych - przyp. autora] wynika nie tylko bezpośrednio z Traktatu - tak jak w przypadku art. 113 (133) i 114 (uchylony) TWE dotyczących umów celnych i handlowych oraz $\mathrm{z}$ art. 238 (310) TWE dotyczącego umów o stowarzyszeniu - ale może w równym stopniu być wywodzona z innych postanowień Traktatu oraz środków przyjętych na ich podstawie przez instytucje wspólnotowe. [...]"16.

W praktyce stosunków międzynarodowych, jak również orzecznictwie Trybunału Sprawiedliwości, podmiotowość prawnomiędzynarodowa Wspólnot, przejawiała się w możliwości nawiązywania stosunków dyplomatycznych z państwami trzecimi i organizacjami międzynarodowymi w tym zdolnością do nabywania członkostwa w tych ostatnich. Wspólnoty, korzystały z prawa legacji (czynnej i biernej). Ponosiły również odpowiedzialność prawnomiędzynarodową za swoje działania, podobnie jak inne organizacje międzynarodowe. Ze względu na fakt, że wyżej wskazane uprawnienia Wspólnot Europejskich zostały uznane przez ponad 2/3 państw i organizacji na świecie, ich podmiotowość do czasu wejścia w życie Traktatu z Lizbony zasadniczo nie była poddawana w wątpliwość.

\section{Status prawnomiędzynarodowy Unii Europejskiej przed 1 grudnia 2009 r.}

O ile zaliczenie Wspólnot Europejskich do organizacji międzynarodowych nie budziło w doktrynie wątpliwości, o tyle poważnych trudności nastręczało pytanie o charakter prawnomiędzynarodowy Unii Europej-

16 Sprawa 22/70 Komisja Wspólnot Europejskich v. Rada Wspólnot Europejskich (sprawa ERTA), Zb. Orz. 1971, s. 263 (tłumaczenie własne). Wyżej wskazane stanowisko ETS w kwestii prawa Wspólnoty do zaciągania zobowiązań międzynarodowych w całej sferze zadań określonych w Części Pierwszej Traktatu wynika także m.in. z wyroku w sprawie Cornelis, Kramer i inni, Zb. Orz. 1976, s. 1279 oraz Opinii 1/76, Zb. Orz. 1977, s. 741. Z tej ostatniej wywiedziono prawo Wspólnoty do zaciagania przez nią zobowiązań międzynarodowych potrzebnych do osiagnięcia danego celu nawet w braku odpowiedniego wyraźnego postanowienia. Jednakże, jak wynika z opinii, zawarcie umowy międzynarodowej przez Wspólnotę nie może oznaczać rezygnacji z niezależności podejmowanych przez nią działań w sferze jej stosunków zewnętrznych ani zmiany jej struktury wewnętrznej, tj. istotnych elementów porządku Wspólnoty, w zakresie uprawnień jej organów, procedury podejmowania decyzji oraz wzajemnej pozycji państw członkowskich. 
skiej. W stanie prawnym wyznaczonym przez TWE, zmodyfikowanym postanowieniami Traktatu z Nicei oraz Traktatów Akcesyjnych państw, które dołączyły do Unii w 2004 i 2007 r. uwidocznił się brak zgody odnośnie tego, czy wskazane wyżej ugrupowanie integracyjne można było zaliczyć do grona organizacji międzynarodowych. Trudności interpretacyjnych nastręczała też kwestia samej podmiotowości prawnomiędzynarodowej UE rozumianej jako zdolność nabywania przez nią praw i zaciaggania zobowiązań międzynarodowych.

W odniesieniu do pierwszego z poruszonych zagadnień w nauce prawa międzynarodowego dominowały dwa nurty myślowe. Zdaniem zwolenników pierwszego z nich, zwanych tradycjonalistami - Unii Europejskiej przed wejściem w życie Traktatu z Lizbony nie sposób było zaliczyć do podmiotów prawa międzynarodowego. Jedynie bowiem Wspólnota Europejska posiadała wówczas osobowość prawną. Argumentowano, że Unia nie mogła we własnym imieniu wydawać żadnych norm prawnych, zawierać traktatów, zatrudniać pracowników, wnosić pozwów i być pozwaną. Ponadto w imieniu UE działały rządy państw członkowskich. W opinii F. Emmerta i M. Morawieckiego Unia Europejska była zatem kompleksowym systemem zależności i współzależności o charakterze prawnym, proceduralnym, prawotwórczym, instytucjonalnym i politycznym ${ }^{17}$. Tożsamy pogląd zaprezentowali m.in. W. Czapliński, A. Wyrozumska, Z. Brodecki ${ }^{18}$ i J. Tyranowski, który stwierdził, że: „Państwa-strony Traktatu o Unii Europejskiej nie przydały Unii cech organizacji międzynarodowej. Organizacją międzynarodową Unia Europejska więc nie jest. W konsekwencji, Unia Europejska nie ma podmiotowości w prawie międzynarodowym - nie ma więc ani zdolności prawnej, ani zdolności do działania w prawie międzynarodowym. Oznacza to dalej, że Unia nie może ani nabywać praw, ani zaciągać zobowiązań w płaszczyźnie prawa międzynarodowego. W rezultacie, prawa i obowiązki międzynarodowe związane z Unią Europejską (filar II i III) są - w płaszczyźnie prawa międzynarodowego - prawami i obowiązkami samych państw członkowskich"19.

17 F. Emmert, M. Morawiecki, Prawo europejskie, Warszawa-Wrocław 2001, s. XXVI.

${ }_{18}$ Por. W. Czapliński, A. Wyrozumska, Prawo międzynarodowe publiczne. Zagadnienia systemowe, Warszawa 1999 s. 302; Z. Brodecki, Prawo europejskiej integracji, Warszawa 2000, s. 31.

19 J. Tyranowski, op. cit., s. 183. 
Odmienny od tradycjonalistów pogląd na temat charakteru prawnego UE wyrażali tzw. autonomiści. Przedstawiciele tego nurtu myślowego - Ch. Zacker i S. Wernicke - wskazywali, iż: „Istnieje daleko idąca zgodność co do tego, że Unia Europejska jest organizacją międzynarodową. Pod tym pojęciem należy rozumieć z założenia trwały związek co najmniej dwóch podmiotów prawa międzynarodowego publicznego oparty na umowie międzynarodowej, zmierzający do realizacji wspólnych celów o charakterze publicznym, ale nie fiskalnym, przy pomocy własnych organów"20. Autorzy ci podkreślali, że posiadanie osobowości prawnej nie jest warunkiem sine qua non uznania swoistej wspólnoty państw za organizację międzynarodowa, o czym świadczy przykład Unii Gospodarczej Państw Beneluxu czy OBWE. Warto zauważyć, że wyżej wskazane stanowisko zostało poparte praktyką orzeczniczą niemieckiego trybunału konstytucyjnego. Uznał on Unię Europejską za związek państw (z niem. Staatenverbund), który realizuje swoje zadania na poziomie międzyrządowym przy poszanowaniu integralności i suwerenności poszczególnych państw, za pomocą autonomicznego systemu prawnego, obowiązującego wszystkich członków $\mathrm{UE}^{21}$. Zwolennikiem poglądu o uznaniu Unii Europejskiej za organizację międzynarodową był też m.in. K Borchardt utrzymujący, iż UE wykracza poza sam cel programowy integracji. Można ją zakwalifikować do kategorii organizacji międzynarodowych ze względu na pełnione przez nią funkcje. W odniesieniu do Wspólnot przejawiają się one w stworzeniu ram prawnych dla ich działalności. Te ostatnie stanowią zatem substrat instytucjonalny UE. Z kolei wobec państw członkowskich funkcje Unii są skupione na zapewnieniu podejmowania przez nie wspólnych działań i form współpracy.

Powołane piśmiennictwo wskazuje na trudności, zaistniałe przed wejściem w życie Traktatu z Lizbony, a dotyczące wypracowania jednolitej, wyraźnej koncepcji dotyczącej statusu prawnomiędzynarodowego UE. W przypadku uznania tego ugrupowania za organizację międzynarodową, trzeba by ją traktować jako określoną formę współpracy państw, a także innych podmiotów prawa międzynarodowego, opartą na umowie międzynarodowej, posiadającą stałe organy i realizującą samodzielnie cele.

Dokonując analizy wyżej wskazanych cech organizacji międzynarodowej, na gruncie UE, warto odwołać się też do obszernych rozważań

${ }^{20}$ Ch. Zacker, S. Wernicke, Prawo europejskie $w$ pytaniach $i$ odpowiedziach, Warszawa 2000, s. 16.

21 Podobnie w: Prawo instytucjonalne Unii Europejskiej, red. M. M. Kenig-Witkowska, Warszawa 2008, s. 40-41. 
dokonanych przez C. Mika ${ }^{22}$. Zdaniem tego autora Unia w okresie przedlizbońskim posiadała solidne podstawy działania, bowiem jej konstrukcja prawna została w głównej mierze oparta na Traktacie z Maastricht. Tenże akt można było postrzegać jako statut organizacji międzynarodowej. Spełniał on wymogi stawiane traktatom międzynarodowym przez Konwencję wiedeńską o prawie traktatów z 23.05.1969 r. ${ }^{23}$ Pewne zastrzeżenia budził jednak fakt, że Traktat o Unii Europejskiej nie włączył do swojej treści traktatów założycielskich, a jedynie zmodyfikował bądź usunął niektóre ich zapisy niezgodne z duchem TUE. Jednakże jak widać na przykładzie poszczególnych zapisów TWE i TUE wymóg aksjologicznej spójności zasad funkcjonowania trzech filarów został spełniony, a konkretne postanowienia nie były ze sobą sprzeczne. Wskazywał na to zwłaszcza art. 47 TUE (odpowiednio art. 40 nowego TUE w wersji skonsolidowanej), w którym zawarto regułę braku kolizji tego aktu z TWE, TEWEA a także późniejszymi traktatami i zmieniającymi lub uzupełniającymi je aktami prawnymi. Ponadto z faktu, że w kwestii przyjmowania nowych państw członkowskich do Wspólnot i Unii obowiązywała jednolita procedura określona w art. 49 TUE oraz, że na gruncie uregulowań zawartych w TWE niemożliwe było, aby przystapić tylko do Wspólnot i jednocześnie pozostawać poza Unią przyjmowano wniosek, iż przepisy TUE obejmują postanowienia traktatów założycielskich Wspólnot. Konkluzja ta wyraźnie została zaakcentowana w początkowych postanowieniach TUE. Jak bowiem wynikało z art. 1 akapit 3 „Unię stanowią Wspólnoty Europejskie, uzupełnione politykami i formami współpracy przewidzianymi niniejszym traktatem". Ponadto jednym z najważniejszych celów Unii było pełne zachowanie dorobku wspólnotowego i jego rozwój (art. 2), możliwe dzięki oparciu się zasadzie jednolitych ram instytucjonalnych (art. 3) przy założeniu, że instytucje Wspólnot określone $\mathrm{w}$ art. 7 ust. 1 TWE będą realizować swoje uprawnienia ,zgodnie z warunkami i celami przewidzianymi, z jednej strony, w postanowieniach Traktatów ustanawiających Wspólnoty Europejskie oraz późniejszych traktatów i aktów zmieniających je lub uzupełniających, z drugiej zaś - w innych postanowieniach niniejszego Traktatu" (art. 5 TUE).

O ile Unia w okresie przedlizbońskim spełniała podstawowy warunek zakwalifikowania jej jako organizację międzynarodową - działała bo-

22 Zob. C. Mik, Europejskie prawo wspólnotowe. Zagadnienia teorii i praktyki, t. I, Warszawa 2000.

23 Dz. U. 1990, Nr 74, poz. 439. 
wiem na podstawie umowy międzynarodowej - to problem stanowiło, czy dysponuje ona samodzielnymi organami oraz realizuje cele autonomiczne od wspólnotowych. Autonomiści podkreślali, że dzięki zapisom art. 3 (ramy instytucjonalne) oraz 5 dawnego TUE (instytucje) UE ,zaadaptowała" instytucje Wspólnot dla swoich celów, zwłaszcza że zgodnie z art. 1 akapit 3 te ostatnie stanowiły część składową większego organizmu prawnego, którym jest Unia Europejska. Zwolennicy poglądu o uznaniu UE za organizację międzynarodową przekonywali ponadto, że ugrupowanie to posiadało całkowicie odrębną instytucję, którą zgodnie z art. 4 TUE była Rada Europejska. Działała ona wyłącznie i jedynie w ramach Unii, a jej szczególna rola przejawiała się w nadawaniu Unii impulsów niezbędnych do jej rozwoju i określaniu w tej mierze ogólnych kierunków politycznych. Wskazywano, że w powiązaniu z instytucjami Wspólnot tworzy ona komplementarny system instytucjonalny.

Z kolei zdaniem tradycjonalistów Unia jedynie ,wypożyczyła” instytucje wspólnotowe (Radę, Komisję, Parlament, Trybunał Sprawiedliwości, Trybunał Obrachunkowy) do realizacji swoich celów i działań, a system instytucjonalny został ukształtowany jedynie w ramach Wspólnot. Ich zdaniem w TWE nie umieszczono Rady Europejskiej w obrębie systemu instytucjonalnego Wspólnot. Co więcej sam Traktat z Maastricht nie rozstrzygał czy Rada Europejska jest instytucja, czy organem.

Jeszcze mniej klarownie w okresie przedlizbońskim przedstawiała się kwestia samodzielności celów i zadań Unii. Analiza art. 2 TUE i 2 TWE wskazywała, że jedynie drugi i czwarty z celów Unii mają charakter autonomiczny i wskazujący na jej odrębność od Wspólnot w prawie międzynarodowym. Dotyczyły one bezpośrednio II i III filaru, tj. potwierdzenia tożsamości Unii na arenie międzynarodowej poprzez realizację WPZiB oraz określanie WPO, a także utrzymania i rozwijania Unii jako przestrzeni wolności, bezpieczeństwa i sprawiedliwości. Warto tutaj zauważyć, że w odniesieniu do II filaru zwolennicy uznania UE za organizację międzynarodową wykazywali, że po nowelizacji przepisów TUE przez Traktat z Amsterdamu ustanowiono urząd Wysokiego Przedstawiciela do Spraw Polityki Zagranicznej i Bezpieczeństwa, który będąc jednocześnie Sekretarzem Generalnym Rady UE (art. 207 ust. 2 TWE), wspomagał ją w sprawach objętych Wspólną Polityką Zagraniczną i Bezpieczeństwa. Przyczyniał się on zatem do formułowania, opracowywania oraz wprowadzania w życie decyzji politycznych, a w stosownych wypadkach, działając w imieniu Rady i na zlecenie Prezydencji, prowadził dialog polityczny ze stronami trzecimi (art. 26 TUE). Co istotne zmiany w przepisach TUE wprowadzo- 
ne przez Traktat z Amsterdamu stworzyły w art. 24 i 38 Traktatu z Maastricht podstawę do zawierania umów międzynarodowych w II i III filarze, co zdaniem autonomistów należało uznać za podstawowy atrybut podmiotowości prawnomiędzynarodowej UE. Tutaj jednak pojawiały się poważne wątpliwości. Brały się one z faktu, że zdolność traktatowa, a więc zdolność do tego ażeby zawierać dwu- i wielostronne umowy międzynarodowe, choć jest podstawą osobowości prawnomiędzynarodowej państwa lub organizacji międzynarodowej, to występuje obok, a nie zamiast pozostałych jej elementów, jakimi są np. prawo legacji (czynnej i biernej), zdolność do stawania przed międzynarodowymi organami powołanymi do rozstrzygania sporów (zdolność procesowa), zdolność do ponoszenia odpowiedzialności prawnej oraz prawo korzystania z przywilejów i immunitetów międzynarodowych.

Niewystępowanie po stronie UE wyżej wymienionych elementów konstytuujących osobowość prawnomiędzynarodową, potwierdzone dodatkowo brakiem w Traktacie o Unii Europejskiej jakiegokolwiek zapisu o podmiotowości międzynarodowej wskazywały zatem, że Unii Europejskiej przed wejściem w życie Traktatu z Lizbony osobowości takiej odmówiono. Jej brak stanowił argument koronny przeciwko uznaniu jej za organizację międzynarodową. Jednakże biorąc pod uwagę posiadanie przez nią podstawy traktatowej w postaci TUE, odrębnej i jedynej instytucji - Rady Europejskiej, częściowo autonomicznych celów oraz niektórych atrybutów osobowości prawnomiędzynarodowej Unię Europejską można było za J. Galsterem i Z. Witkowskim zakwalifikować ostatecznie jako specyficzny twór in statu nascendi obejmujący pod względem kompetencyjnym zasadniczo wszystkie strefy aktywności państwa, działający z jednej strony w oparciu o Wspólnoty i ich system instytucjonalny, a z drugiej przysługujący jej tylko zakres właściwości uzupełniony wspólną polityką zagraniczną i bezpieczeństwa, obronną oraz współpracy w obszarze sprawiedliwości i spraw wewnętrznych ${ }^{24}$.

\section{Status prawnomiędzynarodowy Wspólnot i UE po wejściu z życie Traktatu z Lizbony}

Już podczas prac Konwentu UE przygotowującego Traktat ustanawiający Konstytucję dla Europy stało się jasne, że w celu wzmocnienia

24 Por. J. Galster, Z. Witkowski, Kompendium wiedzy o Unii Europejskiej, TNOiK, Toruń 1996, s. 116. 
tożsamości politycznej UE należy ją przekształcić w organizację międzynarodową. Traktat ów miał w rzeczywistości określić spójne i jednolite reguły jej funkcjonowania, a zatem jak słusznie wskazuje M. Wróblewski byłby swoistym aktem konstytucyjnym czy też statutem UE jako organizacji międzynarodowej, a nie konstytucją europejską ${ }^{25}$. Zgodnie z art. I-7 Traktatu konstytucyjnego UE zostałaby przekształcona ze struktury międzynarodowej o charakterze sui generis w organizację międzynarodową dzięki nadaniu jej osobowości prawnej. Ze względu na to, że zabieg ten byłby poparty uchyleniem bądź zmianą wcześniejszych traktatów (TUE, TWE - art. IV-437) oraz zapewnieniem jej sukcesji i ciagłości prawnej (art. IV-438) „nowa” Unia objęłaby zarówno Wspólnotę Europejską (Euratom istniałby dalej $\mathrm{w}$ obecnej postaci), jak i UE.

Odrzucenie przez obywateli Francji Traktatu konstytucyjnego w referendum z 29 maja 2005 r., a kilka dni później także przez obywateli Holandii, postawiło pod znakiem zapytania możliwość przeprowadzenia gruntownej reformy UE, a co za tym idzie jednoznacznego sprecyzowania jej charakteru prawego. Szansa na zmianę zaistniałej sytuacji pojawiła się podczas spotkania Rady Europejskiej (21-23 czerwca 2007 r.), gdzie przyjęto mandat dla Konferencji Międzyrządowej, określający „mapę drogową" dalszego działania, a także uzgodnienia dotyczące zasadniczej treści reformy $\mathrm{UE}^{26}$. Pozwoliły one na przyspieszenie prac przez prezydencję portugalską nad nowym traktatem rewizyjnym, którego treść ustalono ostatecznie na szczycie Rady Europejskiej w Lizbonie (18-19 października 2007 r.) i ostatecznie podpisano w tym samym miejscu 13 grudnia 2007 r.

Wejście w życie Traktatu z Lizbony, poprzedzone długotrwałą procedurą ratyfikacyjna, spowodowało przyznanie Unii osobowości prawnej (art. 47 TUE w wersji skonsolidowanej), co nastapiło równolegle do likwidacji Wspólnoty Europejskiej. Zgodnie z art. 1 nowego TUE „Podstawę Unii stanowi niniejszy Traktat [TUE - przyp. autora] oraz Traktat o funkcjonowania Unii Europejskiej [...] Oba te traktaty mają taką samą moc prawną. Unia zastępuje Wspólnotę Europejską i jest jej następcą prawnym”. Jak słusznie zauważa J. Barcz na mocy powyższych postano-

25 M. Wróblewski, Dyskurs konstytucyjny w Unii Europejskiej-pojęcie konstytucji i konstytucjonalizmu w porzqdku prawnym Unii Europejskiej, w: Konstytucja dla Europy. Przyszły fundament Unii Europejskiej, red. S. Dudzik, Kraków 2005, s. 69 i n.

J. Barcz, Przewodnik po Traktacie z Lizbony. Traktaty stanowiace Unię Europejskq. Stan obecny oraz teksty skonsolidowane w brzemieniu Traktatu z Lizbony, Warszawa 2008, s. 39. 
wień likwidacji uległ system filarowy, zastapiony ,,jednolitym reżimem prawnym Unii jako spójnej organizacji międzynarodowej"27. Zmiana ta wzmocniła tożsamość Unii na poziomie międzynarodowym oraz zakończyła trwającą wiele lat debatę nad jej charakterem prawnym.

O ile w Traktacie o Unii Europejskiej zawarto przepisy pozwalające uznać ją za organizację międzynarodową o tyle w Traktacie o funkcjonowaniu Unii Europejskiej zawarto prawne podstawy umożliwiające jej działanie na forum międzynarodowym. W art. 216 ust. 1 TFUE nadano Unii prawo do zawierania umów międzynarodowych z państwami trzecimi lub organizacjami międzynarodowymi w następujących przypadkach ${ }^{28}$ :

a) jeżeli przewidują to traktaty;

b) gdy zawarcie umowy jest niezbędne do osiąnnięcia w ramach polityk Unii jednego z celów, o którym mowa w traktatach;

c) gdy zawarcie umowy jest przewidziane w prawnie wiążącym akcie Unii;

d) gdy zawarcie umowy może mieć wpływ na wspólne zasady lub zmienić ich zakres.

Istotnym novum, wprowadzonym do art. 3 ust. 2 TFUE jest też jasne wytyczenie kompetencji wyłącznych UE. Zgodnie z powyższym przepisem ma ona przynależną jej tylko kompetencję do zawierania umów międzynarodowych, w następujących przypadkach:

a) jeżeli ich zawarcie zostało przewidziane w akcie prawodawczym Unii;

b) jest to niezbędne do umożliwienia Unii wykonywania jej wewnętrznych kompetencji;

c) w zakresie, w jakim ich zawarcie może wpływać na wspólne zasady lub zmieniać ich zakres.

W kontekście podmiotowości prawnomiędzynarodowej UE szczególne znaczenie odgrywa członkostwo państw Unii Europejskiej w organizacjach międzynarodowych. Zwłaszcza dodanie przez Traktat z Lizbony powołanego wyżej art. 3 ust. 2 TFUE, dotyczącego sprecyzowania warunków wyłączności UE do zawierania umów międzynarodowych będzie niewątpliwie odgrywać porządkującą i stabilizującą rolę między źródłami prawa pierwotnego i wtórnego UE, bowiem uregulowanie to w sposób

27 J. Barcz, Zasadnicze reformy strukturalne ustroju Unii Europejskiej, w: Traktat z Lizbony. Gtówne reformy ustrojowe w Unii Europejskiej, red. J. Barcz, Warszawa 2008, s. 60-61.

28 Por. Wersja skonsolidowana Traktatu o funkcjonowaniu Unii Europejskiej, Tytuł V (Umowy Międzynarodowe), art. 216 ust. 1. 
wyraźny odwołuje się do orzecznictwa Trybunału Sprawiedliwości Unii Europejskiej. Wspomniany przepis expicite odnosi się do zasady równoległego wykonywania kompetencji wewnętrznych i zewnętrznych, na którą w odniesieniu do Wspólnoty powołał się ETS w wyroku z 31.03.1971 r. w sprawie Komisja vs. Rada (sprawa ERTA) ${ }^{29}$.

W odniesieniu do współpracy UE z organizacjami międzynarodowymi niezwykle ważny jest także art. 220 ust. 1 TFUE. Jak wynika z jego treści, Unia, w miejsce Wspólnoty Europejskiej, ustanawia wszelkie formy współpracy z organami ONZ i jej organizacjami wyspecjalizowanymi, Radą Europy, Organizacją Bezpieczeństwa i Współpracy w Europie, a także Organizacją Współpracy Gospodarczej i Rozwoju.

Warto wreszcie na koniec zaznaczyć, że wprowadzenie w życie tego Traktatu z Lizbony było przez kilka lat najważniejszym zadaniem stojącym przed państwami członkowskimi UE. Poszczególne rządy miały świadomość, że bez dokonania koniecznych reform rozwój ugrupowania zostanie zahamowany, podobnie jak akcesje krajów do niego kandydujących, takich jak: Chorwacja, Macedonia, Albania i Turcja, a od połowy 2009 r. także Islandia.

Wejście $\mathrm{z}$ życie Traktatu z Lizbony ${ }^{30}$ jest niezwykle istotne $\mathrm{z}$ punktu widzenia określenia prawnomiędzynarodowej pozycji UE, jej relacji ze Wspólnotami oraz państwami członkowskimi. W świetle nowych uregulowań prawnych niewątpliwe stało się, iż:

1) Unia Europejska jest organizacją międzynarodową, a zatem samodzielnym podmiotem prawa międzynarodowego ze względu na posiadanie osobowości prawnej;

2) co do zasady zlikwidowana zostaje konstrukcja „świątyni” czy też „trzech filarów” ponieważ „,następcą prawnym” WE staje się Unia Europejska.

To ostatnie rozwiązanie nie jest jednak pozbawione wad. Z jednej strony przestaje funkcjonować Wspólnota Europejska, która zostaje „pochłonięta" przez regulacje dotyczące UE jako organizacji międzynarodowej. Z drugiej strony z Unii Europejskiej wyłączona zostaje Europejska Wspólnota Energii Atomowej. Świadczą o tym postanowienia Protokołu nr 2 zmieniającego Traktat ustanawiający Europejską Wspólnotę Energii Ato-

29 Por. Sprawa 22/70 Komisja Wspólnot Europejskich v. Rada Wspólnot Europejskich, Zb. Orz. 1971, s. 263.

30 Jego pełna nazwa to: ,Traktat zmieniający Traktat o Unii Europejskiej i Traktat ustanawiający Wspólnotę Europejską". 
mowej, dołączonego do Traktatu z Lizbony ${ }^{31}$. Wynika z nich, że „Wysokie Umawiające się Strony” jednoznacznie zgodziły się na dalsze wywoływanie skutków prawnych przez TEWEA. Europejskiej Wspólnocie Energii Atomowej pozostawiono osobowość prawnomiędzynarodową, bowiem spośród przepisów TEWEA uchylonych przez art. 5 Protokołu (a. 3, 107-132, 136-143, 146-156, 158-163, 165-170, 173, 173a, 175, 177-179a oraz 180b, 181, 183, 183a, 190 i 204) wyłączono art. 184, w którym mowa jest o osobowości prawnej Euratomu. Ponadto w art. 8 i 9 Protokołu powołano w nowym brzmieniu art. 191 i 206 TEWEA. Oba dotycząca atrybutów osobowości prawnej organizacji międzynarodowej. Pierwszy z nich wskazuje na prawo EWEA do korzystania na terytorium państw członkowskich z przywilejów i immunitetów. Przywileje te mają charakter funkcjonalny tzn. dotyczą urzędników i innego personelu wyłącznie w ramach ich działania w zakresie wykonywania obowiązków objętych celami EWEA. Natomiast art. 206 TEWEA w nowym brzmieniu nadanym przez art. 9 Protokołu wyraża ius contrahendi wskazanej wyżej Wspólnoty. Zgodnie z nim Euratom może zawierać z jednym lub większą liczbą państw lub organizacji międzynarodowych umowy ustanawiające stowarzyszenie, przy czym zawiera je Rada, stanowiąc jednomyślnie po konsultacji z Parlamentem Europejskim.

\section{Zakończenie}

Rozważając kwestie podmiotowości prawnomiędzynarodowej i charakteru prawnego Wspólnot i UE trudno nie zgodzić się z poglądem, że ostatnia reforma traktatowa jest największym kompromisem, na jaki obecnie godzą się państwa UE. Pomimo jego niedoskonałości wprowadza on fundamentalny zapis, zgodnie z którym twór in statu nascendi zostaje przekształcony w pełnoprawną organizację międzynarodową. Charakteryzuje się ona posiadaniem osobowości prawnomiędzynarodowej i chociaż jako podmiot prawa międzynarodowego została ustanowiona przez państwa, to poprzez korzystanie z własnego systemu instytucji oraz autonomicznego względem prawa międzynarodowego wspólnotowego porządku prawnego jest nie tylko narzędziem, ale również partnerem w realizacji celów ważnych dla państw Unii. Te ostatnie zachowują pełne prawo nie

31 Por. punkt IIB Aktu końcowego Konferencji Przedstawicieli Rzqdów Państw Członkowskich, Dok. CIG 15/07, Bruksela 3 grudnia 2007 r. 
tylko do utworzenia Unii, ale także do zadecydowania o zaprzestaniu jej funkcjonowania. Ponadto zgodnie z nowym TUE każde z państw członkowskich Unii Europejskiej jest uprawnione zgodnie ze swoimi wymogami konstytucyjnymi do podjęcia decyzji o wystąpieniu z Unii (nowy art. 50 TUE). Jeżeli po pewnym czasie państwo to zdecyduje się na ponowne członkostwo może skorzystać z procedury akcesyjnej zawartej w art. 49 TUE (nowy art. 49) i po spełnieniu wymaganych prawem warunków przystapić do UE na zasadach ogólnych.

Jak można sądzić Traktat z Lizbony stanowi niepełne, a zdaniem niektórych przedstawicieli doktryny prawa europejskiego - ułomne - rozwiązanie. Z jednej bowiem strony obecna trójfilarowa konstrukcja prawna zostaje zastąpiona przez jednolitą organizację międzynarodową, a Wspólnota Europejska przestaje funkcjonować. Z drugiej strony w nowym stanie prawnym pozostawiono Europejską Wspólnotę Energii Atomowej. Niekonsekwencja ta wynika w dużej mierze z braku ostatecznego porozumienia pomiędzy państwami członkowskimi co do przyszłej kwalifikacji prawnej UE. Zgodnie ze stanowiskiem krajów takich jak: Niemcy czy Austria powinna ona przyjąć postać zbliżoną do federacji, gdzie jasno byłaby określona struktura podziału kompetencji pomiędzy centrum a jego częściami składowymi. Inne podejście przyjmują np. Francja i Polska. Kraje te są zwolennikami UE jako związku państw (konfederacji), gdzie państwa członkowskie wyznaczają kierunek działań Unii. Unia Europejska jako organizacja międzynarodowa stanowi próbę pogodzenia obu stanowisk. Czy ta forma prawna jej działalności, wprowadzona Traktatem lizbońskim, jest docelowym modelem prawnym integracji pokaże niedaleka przyszłość.

\section{Bibliografia}

Aktu końcowy Konferencji Przedstawicieli Rzq̨ów Państw Członkowskich, Dok. CIG 15/07, Bruksela 3 grudnia 2007.

Barcz J., Przewodnik po Traktacie z Lizbony. Traktaty stanowiqce Unię Europejska. Stan obecny oraz teksty skonsolidowane $w$ brzemieniu Traktatu z Lizbony, Warszawa 2008.

Barcz J., Zasadnicze reformy strukturalne ustroju Unii Europejskiej, w: Traktat z Lizbony. Gtówne reformy ustrojowe w Unii Europejskiej, red. J. Barcz, Warszawa 2008.

Brodecki Z., Prawo europejskiej integracji, Warszawa 2000. 
Czapliński W., Wyrozumska A., Prawo międzynarodowe publiczne. Zagadnienia systemowe, Warszawa 1999.

Emmert F., Morawiecki M., Prawo europejskie, Warszawa-Wrocław 2001.

Galster J., Witkowski Z., Kompendium wiedzy o Unii Europejskiej, TNOiK, Toruń 1996.

Hirst P., Thompson P. G., Globalisation and the Nation State, w: The Handbook of Globalisation, ed. J. Michie, Chaltenham 2003.

Klafkowski A., Prawo międzynarodowe publiczne, Warszawa 1966.

Konwencja wiedeńska o prawie traktatów z 23.05.1969 r. (Dz. U. 1990, Nr 74, poz. 439).

Mik C., Europejskie prawo wspólnotowe. Zagadnienia teorii i praktyki, t. I, Warszawa 2000.

Opina ETS 1/76, Zb. Orz. 1977, w: W. Czapliński, R. Ostrihansky, P. Saganek, A. Wyrozumska, Prawo Wspólnot Europejskich. Orzecznictwo, Warszawa 2005.

Prawo Unii Europejskiej, pod red. J. Barcza, Warszawa 2006.

Prawo instytucjonalne Unii Europejskiej, red. M. M. Kenig-Witkowska, Warszawa 2008.

Czapliński W., Ostrihansky R., Saganek P., Wyrozumska A., Prawo Wspólnot Europejskich. Orzecznictwo, Warszawa 2005.

Schweitzer M., Hummer W., Europarecht. Das Recht der Europäischen Gemeinschaften (EKGS, EWG, EAEG) - mit Schwerpunkt EG, Berlin 1996.

Sprawa 6/64, Flamino Costa v. ENEL, Zb. Orz. 1964.

Sprawa 22/70 Komisja Wspólnot Europejskich v. Rada Wspólnot Europejskich (sprawa ERTA), Zb. Orz. 1971.

Sprawa Cornelis, Kramer i inni, Zb. Orz. 1976.

Tyranowski J., Prawo europejskie, Poznań 2005.

Wróblewski M., Dyskurs konstytucyjny w Unii europejskiej-pojęcie konstytucji i konstytucjonalizmu w porzqdku prawnym Unii Europejskiej, w: Konstytucja dla Europy. Przyszły fundament Unii Europejskiej, red. S. Dudzik, Kraków 2005.

Zacker Ch., Wernicke S., Prawo Europejskie w pytaniach i odpowiedziach, Warszawa 2000 .

\section{Summary}

One of the main issues in the debate on the Treaty of Lisbon was to determine the legal international status of the European Union. The doctrine of international public law and European law stipulates personality as the ability to acquire rights and enter into international commitments. Before the Treaty of Lisbon came into force a highly animated and varied discussion continued on this issue. Among other things, it con- 
cerned the issues of whether international organizations are the subjects of international law, the nature of their subjectivity (primary or secondary), the relationship between the Community's founding treaties, and, finally, whether European law constitutes an autonomous legal system. The most serious controversies, however, were raised by the legal international qualification of the European Union. In the opinion of a portion of representatives of European law, the EU was considered to be an international organization although it did not have legal personality, in contrast to the European Community. Therefore, it was usually defined as a specific structure in statu nascendi. This dispute was ultimately concluded by the Lisbon Treaty which replaced the three-pillar legal structure with a uniform international organization, and the European Community ceased to function. Yet the new legal system retained the European Atomic Energy Community, which seems an inconsistent and flawed decision, albeit a politically justified solution. 